\title{
Generation differences in hospital inpatient care of children aged 1 to 5 years
}

\author{
M E J Wadsworth, S L Mann, E Jones
}

\begin{abstract}
Study objective-To describe differences in childhood hospital admissions at ages 1 to 5 years in two generations, and to compare the intergenerational differences in risks of admission.

Design-Information was taken from a longitudinal birth cohort study of a national sample and their firstborn offspring. Setting-England, Wales, and Scotland. Subjects-the 5022 birth cohort members for whom information is available from ages 1 to 5 years and their 2205 firstborn offspring. Measurements and main results-Data comprised reports of hospital admissions, which were checked with hospitals. Mean numbers of days spent in hospital were fewer in the offspring generation than in their parents, but the proportion ever admitted fell by only $1 \%$. Low birth weight babies $(<2500$ g), who comprised $6 \%$ of cohort births and $7 \%$ of the following generation, used a high proportion of all inpatient time in the offspring population, rising from $3 \%$ to $14 \%$ of all days of admission.
\end{abstract}

Conclusions-Compared with the early years of the NHS, published statistics show that the effectiveness of paediatric care has improved greatly, and that childhood mortality and the risk of serious illness have decreased significantly. This study reports intergenerational changes in the reasons for hospital admission and shows, with the benefit of good denominator data, that although there was only a small intergenerational decrease in the proportion of children treated in hospital, there was a large reduction in the time spent in hospital and an increase in admissions of children of low birth weight.

f Epidemiol Community Health 1993; 47: 149-152

MRC National Survey

of Health and

Development,

University College and

Middlesex School of

Medicine, University

College London,

Department of

Epidemiology and

Public Health, 66-72

Gower Street, London

WC1E 6EA

$M$ E J Wadsworth

$S$ L Mann

Enfield Health

Authority, Public

Health Directorate,

London

E Jones

Correspondence to:

Professor M E J Wadsworth

Accepted for publication October 1992 actual ratios of 12.7 thousand children per medically qualified paediatric staff in $1967,{ }^{3} 5.4$ thou- sand in $1977,{ }^{45}$ and 3.5 thousand in $1987 .{ }^{46}$ The outcome of this investment in knowledge, manpower, health education, and the 'social and educational approach', ${ }^{7}$ has been a dramatic improvement in most aspects of survival in infancy, and a considerable reduction in the risk of many kinds of illness in childhood. ${ }^{8}$

Despite these improvements, concerns remain about NHS costs. Birth and old age are the two most costly times of life in terms of hospital care. In 1988-89 the annual costs for hospital and community health services per head of the population were highest for those aged 85 years and over (£1995) and for births (£1383); the least expensive ages were 16-44 years $(£ 85), 5-15$ years $(£ 113), 45-66$ years $(£ 193)$, and $0-4$ years $(£ 229) .{ }^{10}$

There is concern that continuing improvements in survival rates in both the old and young (these already costly sections of the population in terms of medical care) will mean rising expenditure to meet the anticipated greater morbidity of these groups. Among children, the increased survival of those of low and very low birth weight seems more likely to be a source of commensurate increase in handicap and impairment ${ }^{11}$ and in demand for medical care ${ }^{12-14}$ than was once believed. ${ }^{1516}$

There has been, in general, a rise in the rate of children's admissions to hospital, ${ }^{17} 18$ and in the numbers of admissions of children. ${ }^{19}$ Comparison of numbers of admissions of children from the same catchment area over 10 years in an English industrial city showed an increase of $100 \% .^{17}$ Comparison of admissions before the age of 5 years among representative national populations showed a rise from $18.5 \%$ admitted of the study population born in 1946 to $25.5 \%$ admitted of those born in $1970 .^{20}$ Admissions of children under age 14 years have also risen, for example, from $22 \cdot 3$ per thousand of the population of that age in 1974 to 38.6 per thousand in $1984 .{ }^{1}$ This rise has been attributed to an increase in early diagnoses and treatment of serious illness, ${ }^{21}$ to new possibilities for the treatment of such previously practically untreatable problems as 'congenital heart disease, certain renal disorders, and malignancies', and to admission 'as a protective measure against a possible risk of legal claims'. ${ }^{1}$ Some admissions, found to be as much as $20 \%$ in $1977^{22}$ and $9 \%$ in a recent study ${ }^{17}$ in the same industrial city, may also be undertaken or prolonged because of poor home circumstances.

This paper uses data from a national birth cohort study and its offspring to compare hospital admissions among children aged $1-5$ years in the two generations. Such good denominator data allow comparison of risks of admission to be expressed per head of the 'at risk' population. 


\section{Methods}

Findings are reported from the Medical Research Council's National Survey of Health and Development (NSHD) a longitudinal study, so far from birth to age 43 years, of a national class stratified sample $(n=5362)$ of all births that occurred in one week in 1946 in England, Wales, and Scotland. Up to age 15 years, data were collected 10 times on this cohort's health, growth, development, and home and family circumstances, and a further nine times in adult life. Information on hospital admissions was collected on each occasion retrospectively to the last time of contact and checked with hospital records.

The first offspring born to this cohort while they were aged 19 to 25 years $(n=2205)$ were studied twice in childhood, and information on their hospital admissions was collected in the same way as for their parents. ${ }^{23} 24$

Hospital admissions were coded using information collected between ages 1 to 5 years in each generation. Since admissions during the first year of life did not always report neonatal care, this period has been omitted. Mothers' reports of admissions were checked with hospital records, and final diagnoses were coded using the International Standard Classification Code of Diseases and Causes of Death (ICD). ${ }^{25}$

Since the offspring generation comprise only firstborn children of cohort members aged 19-25 years, the findings are compared between the generations using the offspring generation in comparison with both the whole cohort and with cohort members who were the firstborn of mothers aged $19-25$ years.

Relative risks and their confidence intervals were calculated to compare rates of admission among sub groups of cohort members and offspring. Median lengths of stay in hospital were compared using the Wilcoxon test for two independent samples; for more than two samples the Kruskal-Wallis statistic was calculated.

Table I Percentage of children admitted to hospital between age 1 and 5 years in the birth cohor (born 1946) and their firstborn offspring (born 1965-1971)

\begin{tabular}{lll}
\hline & Cohort & Offspring \\
\hline \% admitted once & $13 \cdot 4(13 \cdot 6)^{\star}$ & $11 \cdot 6$ \\
\% admitted more than once & $2 \cdot 6(2 \cdot 5)^{\star}$ & $3 \cdot 4$ \\
\% not admitted & $84 \cdot 0(84 \cdot 0)^{\star}$ & $85 \cdot 0$ \\
Total (=100\%) & $5022(848)^{\star}$ & 2205 \\
\hline ॠFigure in brackets are findings for first born cohort members
\end{tabular}
born to mothers aged 19-25 years.

Table II Comparison of the seven most common reasons for hospital admission, and the $\%$ of admissions attributed to that reason, in the birth cohort (total and firstborn) and their firstborn offspring aged 1-5 years

\begin{tabular}{|c|c|c|c|c|c|c|}
\hline & $\begin{array}{l}\text { Total cohort } \\
\text { (admitted } \\
\text { 1947-51) }\end{array}$ & & $\begin{array}{l}\text { Firstborn } \\
\text { cohort members * } \\
\text { (admitted } \\
1947-51 \text { ) }\end{array}$ & & $\begin{array}{l}\text { Offspring } \\
\text { (admitted } \\
\text { 1966-76) }\end{array}$ & \\
\hline $\begin{array}{l}\text { Most common } \\
\text { reason }\end{array}$ & Respiratory & $(37 \cdot 3 \%)$ & Respiratory & $(40 \cdot 8 \%)$ & Injury & $(21 \cdot 0 \%)$ \\
\hline $\begin{array}{l}\text { 2nd reason } \\
\text { 3rd reason } \\
\text { 4th reason } \\
5 \text { th reason } \\
\text { 6th reason } \\
7 \text { th reason } \\
\text { Total number of } \\
\text { admissions for all } \\
\text { causes including } \\
\text { those not shown } \\
\text { here. }\end{array}$ & $\begin{array}{l}\text { Infections } \\
\text { Digestive } \\
\text { Injury } \\
\text { Eye and ear } \\
\text { Ill defined } \\
\text { Genitourinary } \\
1000\end{array}$ & $\begin{array}{r}(18 \cdot 7 \%) \\
(9 \cdot 2 \%) \\
(8 \cdot 7 \%) \\
(8 \cdot 3 \%) \\
(4 \cdot 5 \%) \\
(3.8 \%)\end{array}$ & $\begin{array}{l}\text { Infections } \\
\text { Injury } \\
\text { Digestive } \\
\text { Eye and ear } \\
\text { Ill defined } \\
\text { Genitourinary } \\
169\end{array}$ & $\begin{array}{r}(13.6 \%) \\
(13.0 \%) \\
(8.3 \%) \\
(7.7 \%) \\
(5.9 \%) \\
(3.6 \%)\end{array}$ & $\begin{array}{l}\text { Respiratory } \\
\text { Genitourinary } \\
\text { Ill defined } \\
\text { Digestive } \\
\text { Congentital } \\
\text { Eye and ear } \\
\mathbf{4 4 3}\end{array}$ & $\begin{array}{r}(19.9 \%) \\
(12.9 \%) \\
(10.1 \%) \\
(9.7 \%) \\
(8.3 \%) \\
(6.1 \%)\end{array}$ \\
\hline
\end{tabular}

\section{Results}

THE EXTENT OF HOSPITAL ADMISSION

Hospital admissions at ages one to five years are shown in table 1. Despite an intergenerational fall of $1 \%$ in the proportion ever admitted there was an increase among those admitted more than once.

Risk of admission among all cohort members whose fathers were in manual occupations was not significantly different to that among all those whose fathers were in non-manual social class occupations $(\mathrm{RR}=1 \cdot 09,95 \% \mathrm{CI}=0.95,1 \cdot 24$; $\mathrm{p}=\mathrm{NS}$ ), or among those who were firstborn $(R R=0 \cdot 89,95 \% \mathrm{CI}=0 \cdot 68,1 \cdot 30 ; \mathrm{p}=\mathrm{NS})$.

Among the offspring there was a significantly lesser risk of hospital admission in those whose fathers worked in non-manual occupations than in those who were unemployed $(R R=0 \cdot 66, C I=0 \cdot 46$, $0.96 ; p<0.05)$, but there was no difference in rates of admission between those with fathers in manual occupatios and those with fathers in non-manual occupations $(\mathrm{RR}=0 \cdot 89, \mathrm{CI}=0 \cdot 72,1 \cdot 11 ; \mathrm{p}=\mathrm{NS})$.

The median time spent in hospital was significantly longer in the cohort children from manual social class families (median stay 11.0 days), and those whose fathers were unemployed or absent (median 11.5 days), compared with those whose fathers were in non-manual employment (median $7 \cdot 0$ days) $(p<\cdot 05)$. Among cohort firstborn children, the length of stay in hospital did not differ significantly between the social groups. Median times spent in hospital by the offspring were shorter, but did not differ significantly between those whose fathers were in non-manual occupations (median 3 days), manual occupations (4 days), or unemployed (4 days).

There was no change in the risk of admission to hospital between the two generations for children from non-manual or manual backgrounds.

\section{REASONS FOR ADMISSION}

In the offspring generation, injury was the most common reason for admission, compared with respiratory illness in the original cohort. Inpatient care for infection was no longer in the top seven reasons for hospital admission in the offspring generation (it accounted for $18,7 \%$ of all cohort admissions and $1.6 \%$ of admissions of offspring), and ill defined conditions and genitourinary and congenital problems received more hospital inpatient care in the offspring generation than among their parents (table II).

\section{TIME SPENT IN HOSPITAL}

There were also generation difference in terms of the time spent in hospital (table III). Mean times spent in hospital per person admitted fell from 22 to 9 days (table IV). The mean number of days for each admission also fell.

The ranking of reasons for hospital admission according to the time spent in hospital showed the great reduction in days of admission for the care of infection (from $43.2 \%$ of all days of admission experienced by the cohort to $1.4 \%$ of days the offspring were admitted) (table III). Mean times spent in hospital by the offspring generation were mostly a third of those spent by the cohort for similar sets of conditions, but average days spent in hospital for the care of infectious disease fell from 36.4 to 4.9 days. 


\section{LOW BIRTH WEIGHT}

In the cohort, $6.0 \%$ of babies were of low birth weight ( $2500 \mathrm{~g}$ or less) $(5 \cdot 4 \%$ of firstborn cohort children) compared with $7 \cdot 1 \%$ of babies who were firstborn to cohort women between 1965 and 1971 . Altogether $17 \cdot 6 \%$ of low birth weight cohort children were admitted to hospital at aged 1-5 years, compared with $29 \cdot 0 \%$ of offspring children at the same ages.

At ages 1 to 5 years in the cohort, low birth weight children spent less time in hospital than others (median $7 \cdot 0$ days, compared with a median of 9.0 days for others; for firstborn cohort children medians were 10.0 days and 6.0 days). In the offspring population, however, children who had been of low birth weight spent more days in hospital (median 6.0 days) than others (median $4 \cdot 0$ days). There were no significant differences in median lengths of stay within the generations.

Low birth weight babies in the cohort consumed a much smaller proportion of all hospital inpatient days $(3.3 \%$ - firstborn cohort members consumed $2 \cdot 6 \%$ of days) than low birth weight offspring in the following generation $(13 \cdot 7 \%)$.

\section{Discussion}

There continues to be concern about the apparently rising numbers of children admitted to hospital, the seeming increasing numbers of admissions, and the extent to which these changes represent improvements in health care. ${ }^{18212628}$ During the life span of the NHS infant and childhood mortality and morbidity have been reduced and, as the study reported here shows, for individual children the length of hospital admission has fallen. Unlike the study of admissions in

Table III Ranking of conditions that required the most days of hospital admission in the study population and their offspring (aged 1-5 years), and the mean (SE) number of days of admission for each group of conditions

\begin{tabular}{|c|c|c|c|c|c|c|}
\hline & $\begin{array}{l}\text { Total cohort } \\
\text { (admitted } \\
1947-51 \text { ) }\end{array}$ & & $\begin{array}{l}\text { Firstborm } \\
\text { cohort members * } \\
\text { (admitted } \\
1947-51 \text { ) }\end{array}$ & & $\begin{array}{l}\text { Offspring } \\
\text { (admitted } \\
1966-76)\end{array}$ & \\
\hline $\begin{array}{l}\text { Highest } \\
\text { percentage } \\
\text { of days of } \\
\text { admission }\end{array}$ & $\begin{array}{l}\text { Infections } \\
36 \cdot 4 \text { days }\end{array}$ & $\begin{array}{c}(43 \cdot 2 \%) \\
(4 \cdot 2)\end{array}$ & $\begin{array}{l}\text { Infections } \\
46 \cdot 70 \text { days }\end{array}$ & $\begin{array}{r}(53 \cdot 8 \%) \\
(14 \cdot 76)\end{array}$ & $\begin{array}{l}\text { Respiratory } \\
5 \cdot 0 \text { days }\end{array}$ & $\begin{array}{c}(19 \cdot 8 \%) \\
(0 \cdot 4)\end{array}$ \\
\hline 2nd highest & $\begin{array}{l}\text { Respiratory } \\
6 \cdot 4 \text { days } \\
\text { Congenital }\end{array}$ & $\begin{array}{l}(13 \cdot 7 \%) \\
(0 \cdot 4) \\
(7 \cdot 1 \%)\end{array}$ & $\begin{array}{l}\text { Musculoskeletal } \\
114 \cdot 75 \text { days } \\
\text { Respiratory }\end{array}$ & $\begin{array}{r}(14 \cdot 7 \%) \\
(87 \cdot 12) \\
(11 \cdot 2 \%)\end{array}$ & $\begin{array}{l}\text { Injury } \\
7 \cdot 0 \text { days } \\
\text { Genitourinary }\end{array}$ & $\begin{array}{l}(15 \cdot 5 \%) \\
(2 \cdot 0) \\
(10.6 \%)\end{array}$ \\
\hline 3rd highest & $\begin{array}{l}\text { Congenital } \\
39 \cdot 7 \text { days }\end{array}$ & $\begin{array}{l}(1 \cdot 1 \%) \\
(17 \cdot 4)\end{array}$ & $\begin{array}{l}\text { Kespiratory } \\
4.99 \text { days }\end{array}$ & $\begin{array}{r}(11 \cdot 2 \%) \\
(0 \cdot 66)\end{array}$ & $4 \cdot 2$ days & $\begin{array}{c}(10.6 \%) \\
(0.9)\end{array}$ \\
\hline 4th highest & $\begin{array}{l}\text { Eye and ear } \\
15.3 \text { days }\end{array}$ & $\begin{array}{l}(6 \cdot 8 \%) \\
(2 \cdot 0)\end{array}$ & $\begin{array}{l}\text { Eye and ear } \\
14.55 \text { days }\end{array}$ & $\begin{array}{r}(4 \cdot 9 \%) \\
(4 \cdot 10)\end{array}$ & $\begin{array}{l}\text { Ill defined } \\
6 \cdot 2 \text { days }\end{array}$ & $\begin{array}{l}(9 \cdot 0 \%) \\
(1 \cdot 0)\end{array}$ \\
\hline 5th highest & $\begin{array}{l}\text { Digestive } \\
12 \cdot 4 \text { days }\end{array}$ & $\begin{array}{l}(6 \cdot 6 \%) \\
(1 \cdot 0)\end{array}$ & $\begin{array}{l}\text { Injury } \\
6 \cdot 86 \text { days }\end{array}$ & $\begin{array}{r}(4 \cdot 8 \%) \\
(1 \cdot 20)\end{array}$ & $\begin{array}{l}\text { Congenital } \\
7 \cdot 6 \text { days }\end{array}$ & $\begin{array}{l}(7 \cdot 4 \%) \\
(1 \cdot 3)\end{array}$ \\
\hline 6th highest & $\begin{array}{l}\text { Injury } \\
13 \cdot 0 \text { days }\end{array}$ & $\begin{array}{l}(6 \cdot 5 \%) \\
(1 \cdot 8)\end{array}$ & $\begin{array}{l}\text { Digestive } \\
10 \cdot 08 \text { days }\end{array}$ & $\begin{array}{r}(4 \cdot 6 \%) \\
(1 \cdot 20)\end{array}$ & $\begin{array}{l}\text { Digestive } \\
4 \cdot 1 \text { days }\end{array}$ & $\begin{array}{l}(7 \cdot 1 \%) \\
(0 \cdot 5)\end{array}$ \\
\hline 7th highest & Genitourinary & $(3 \cdot 6 \%)$ & Ill defined & $(2 \cdot 1 \%)$ & Musculoskeletal & $(5 \cdot 0 \%)$ \\
\hline $\begin{array}{l}\text { Total days } \\
\text { for all causes } \\
\text { including } \\
\text { those not } \\
\text { shown here } \\
(100 \%)\end{array}$ & $\begin{array}{l}17.4 \text { days } \\
17503\end{array}$ & $(0.5)$ & $\begin{array}{l}6 \cdot 25 \text { days } \\
3117\end{array}$ & $(2 \cdot 13)$ & $\begin{array}{l}16 \cdot 9 \text { days } \\
2407\end{array}$ & $(9 \cdot 0)$ \\
\hline
\end{tabular}

Table IV Comparison of hospital infant and early childhood admission (1-5 years) of the total cohort and firstborn cohort members (born 1946) and their firstborn offspring of the total cohort and firstborn
the cohort (born 1965-71)

\begin{tabular}{lllc}
\hline & $\begin{array}{l}\text { Total cohort } \\
(n=5021)\end{array}$ & $\begin{array}{l}\text { Firstborm cohort } \\
(n=844)\end{array}$ & $\begin{array}{l}\text { Offspring } \\
(n=2204)\end{array}$ \\
\hline $\begin{array}{l}\text { Mean (SE) number } \\
\text { of days in hospital }\end{array}$ & $22 \cdot 5$ & $23 \cdot 6$ & $7 \cdot 4$ \\
$\begin{array}{l}\text { per person admitted } \\
\text { Mean (SE) number }\end{array}$ & $(2 \cdot 2)$ & $(7 \cdot 7)$ & $(0 \cdot 6)$ \\
$\begin{array}{l}\text { odmission } \\
\text { admis }\end{array}$ & $15 \cdot 8$ & $14 \cdot 4$ & $5 \cdot 3$ \\
\hline
\end{tabular}

the Oxford region in 1975 and 1984 , however, ${ }^{29}$ there was little generation difference in the risk of admission.

There are anxieties that increased survival of low birth weight babies may bring an increased burden of morbidity and a high rate of demand for inpatient care. ${ }^{14}$ This study may underestimate that problem because the offspring population were born between 1965 and 1971, and since then the chances of survival of low birth weight babies have continued to increase. For example, among those in the national population of birth weight $2000-2499 \mathrm{~g}$, the risk of death in the perinatal period has fallen from $27 \cdot 3$ per thousand total births of that weight in 1986 to $24 \cdot 1$ in $1988:^{30} 31$ but the proportion of babies weighing under 2500 $\mathrm{g}$ at birth still amounts to only $6 \cdot 6 \%$ of the national population of all live births $(4 \cdot 3 \%$ at birth weights $2000-2499 \mathrm{~g}$, and $2 \cdot 2 \%$ at lower birth weights). ${ }^{31}$ Nevertheless this study showed that at ages 1 to 5 years in the offspring population the relatively small proportion of low birth weight offspring babies consumed a high proportion of all hospital inpatient days.

Although a reduction in the time children spend in hospital has been found in this study, it is less likely that a comparable reduction would be found in demand for community care. General practitioner consultations, for instance, rose from 3773.9 per thousand children aged 0 to 4 years in 1971-72 to 4914.9 per thousand in 1981-82. 3233 In most respects increases in admissions to hospital for any reason, and any extra burden of morbidity, handicap, and disability which may be brought by the increased survival of those of low birth weight, ${ }^{11}{ }^{34}$ must be borne not only by hospitals but also by families, by general practitioners, and by community health and welfare services.

We are grateful to our colleagues and to Dr M McCarthy and Professor A Maynard for their comments.

1 Forfar JO. Child health in a changing society. Oxford: Oxford University Press, 1988

2 Ministry of Health. Report of the Minsitry of Health for the year ended 31st December 1959; part 1, Cmnd 1086. London: HMSO, 1960

3 Department of Health and Social Security. Digest of health statistics for England and Wales 1971. London: HMSO, 1971

4 Department of Health. Health and personal social services statistics for England. London: HMSO, Department of Health, 1989

5 Welsh Office. Health and personal social services statistics for Wales, No 5. London: HMSO, Welsh Office, 1978.

Welsh Office. Health and personal social services statistics for Wales, No 10. London: HMSO, Welsh Office, 1989

Douglas JWB, Blomfield JM. Children under five. London: Allen and Unwin Ltd, 1958.

8 Pharoah POD, Alberman ED. Mortality of low birthweight infants in England and Wales 1953-79. Arch Dis Child 1981; 56: $86-89$.

9 Court D, Alberman E. Worlds apart. In: Forfar JO, ed. Child health in a changing society. Oxford: Oxford University Press,
1988. () Department of Health and Office of Population Censuses
and Surveys. The governments's expenditure plans 1991-92 to 1993-94. Cmnd 1513. London: HMSO, 1991

11 Marlow N, d'Souza SW, Chiswick ML. Neurodeve lopmental outcome in babies weighing less than $2001 \mathrm{~g}$ at birth. $B M \mathcal{F}$ 1987; 294: 1582-6

12 Mutch L, Newdick M, Lodwick A. Chalmers I. Secula changes in rehospitalisation of very low birth weight infants Pediatrics 1986; 78: 164-71.

13 Kitchen WH, Ford GW, Doyle LW, Rickards A, Kelly EA Health and hospital readmissions of very-low birth-weigh and normal-birth-weight children. Am $\mathcal{F}$ Dis Child 1990 144: $213-8$.

14 Greenough A, Roberton NRC. Effect of a regional neonatal unit on a general paediatric ward. BMF 1985; 291: 175-6.

15 Stewart AL, Reynolds EOR, Lipscomb AP. Outcome for infants of very low birth weight: survey of world literature. Lancet 1981; i: $1038-41$. 
16 Pape KE, Buncic RJ, Ashby S, Fitzhardinge PM. The statu A weights of less than $1001 \mathrm{gm}$. F Pediatr 1978; 92: 253-60.

17 Hutchison TP, Durojaiye L, Madeley RJ. Improved primary care does not prevent the admission of children to hospital. Arch Dis Child 1987; 62: 649-50.

18 Hill AM. Trends in paediatric medical admissions. $B M \mathcal{F}$ 1989; 298: 1479-83.

19 Pharoah POD, Alberman ED. Annual statistical review. Arch Dis Child 1990; 65: 147-51.

20 Golding J, Haslum M. Hospital admissions. In: Butler NR, Golding J, eds. From birth to five. Oxford: Pergamon Press, 1986

21 Forfar JO. Trends in paediatric medical admissions. $B M F$ 1989; 298: 1711 .

22 Wynne J, Hull D. Why are children admitted to hospital? BMF 1977; 2: 1140-1142.

23 Wadsworth MEJ, Mann SL, Rodgers B, Kuh DJL, Hilder WS, Yusuf EJ. Loss and representativeness in a 43 yea follow-up of a national birth cohort. $\mathcal{F}$ Epidemiol Community Health 1992; 46: 300-4.

24 Wadsworth MEJ. The imprint of time: childhood, history and adult life. Oxford: Oxford University Press, 1991.

25 World Health Organisation. International Statistical Classification Code of Diseases, Injuries and Causes of Death. Geneva: WHO, 1978
26 Lovejoy FH, Carper JM, Janeway CA, Kosa J. Unnecessary and preventable hospitalisations: report on an internal audit. F Pediatr 1971; 79: 868-71.

27 Duff RS, Cook CD, Wanerka GR, Rowe DS, Dolan TF. Use of utilization review to assess the quality of pediatric inpatient care. Pediatrics 1972; 49: 169-76.

28 Kemper KJ. Medically inappropriate hospital use in a pediatric population. $N$ Engl f Med 1988; 318: 1033-7.

29 Henderson J, Goldacre $M$, Griffith $M$. Time spent in hospital by children: trends in the Oxford record linkage study area. Health Trends 1991; 22: 166-9.

30 Office of Population Censuses and Surveys. Mortality statistics, perinatal and infant, 1986. Series DH3, no 20. London: HMSO, 1988.

31 Office of Population Censuses and Surveys Mortality statistics, perinatal and infant, 1988. Series $\mathrm{DH} 3$ no 22. statistics, perinatal and infar

32 Office of Population Censuses and Surveys. Morbidity statistics from general practice 1971-2. Studies on Medical and Population Subjects no 36. London: HMSO, 1979.

33 Office of Population Censuses and Surveys. Morbidity statistics from general practice 1981-2. Series MB5 no 1. London: HMSO, 1986

34 Lefebvre F, Bard H, Veilleux A, Martel C. Outcome at school age of children born with birthweights of 1000 grams or less. Dev Med Child Neurol 1988; 30: 170-80. 